ОСОБЛИВОСТІ ЕМОЦІЙНОЇ ЗБУДЛИВОСТІ СТУДЕНТІВ НА РІЗНИХ ЕТАПАХ НАВЧАННЯ

\title{
FEATURES OF EMOTIONAL STUDENTS EXCITEMENT AT DIFFERENT STAGES THEIR LEARNING
}

У статті розглянуто питання дослідження особливостей емоційної збудливості студентів в процесі їх професійної підготовки. Проаналізовано психологічні особливості прояву емоційної збудливості та їі основні компоненти. Досліджено особливості емочійної збудливості студентів першого та четвертого курсів.

Емоційна збудливість є особистісною особливістю, для якої характерні легкість виникнення сильних емоцій, ослаблений самоконтроль $і$ загальна ефрективність поведінки. Емоційна збудливість може проявлятися в таких особливостях поводження, як запальність, дратівливість.

Емоційна збудливість характеризується тим, якої сили потрібен вплив, щоб викликати емоційну реакцію. Важливим є також поняття емоційної стійкості, яке характеризується емоційною нечутливістю, невразливістю емоційної сфери особистості до дії емоційних подразників, здатністю контролювати емоційні реакції, що проявляється в терплячості, наполегливості, самоконтролі, витримці. Все це забезпечує стійкість ефективності діяльності та підвищення власної самооцінки.

Прояви підвищеної емоційної збудливості різні, аж до діаметрально протилежних: $у$ людини може спостерігатися підвищена рухова активність, імпульсивність, або, навпаки, людина буде здаватися абсолютно спокійною, байдужою, нерухомою, проте збудливість знайде своє вираження у вигляді посилення асоціативної активності (почуття сильного занепокоєння, тривоги, що супроводжується безперервним потоком різних неконтрольованих думок і франтазій). Підвищена емоційна збудливість може стати передумовою виникнення більш небезпечного синдрому, а саме емоційного вигорання.

З точки зору фрізіології, емоційна збудливість $€$ ні чим іншим, як емоційною готовністю, тобто готовністю емоційно реагувати на значущі для людини подразники. Істотну роль у формуванні иієї готовності відіграє адреналін. Його введення піддослідним зумовлювало те, що вони починали виявляти емоційні спалахи на ті подразники, які раніше залишали їх зовсім спокійними. Емоційна збудливість сприяє ефективності деяких видів професійної діяльності. Особистість із надмірною емоційною збудливістю відчуває $і$ сприймає ті речі, які можуть пропустити або не помітити інші. Вона часто звертається до друзів та знайомих за допомогою і порадою через ті міцні зв'язки, які вона будує. Через інтенсивність їхніх почуттів і співчуття до інших у таких людей зазвичай встановлюються дуже міцні дружні стосунки. Їхні почуття до друзів дуже глибокі, тому вони завжди залишаються в рядах найвідданіших друзів.

у тих, хто має емоційну надчутливість, яскраво висловлено співчуття до людей, але мало співчуття до себе. Вони дуже само- критичні, і в них сильно розвинене почуття відповідальності навіть за ті речі, які їм не доручалися.

Ключові слова: емоційна ссрера, профресійна підготовка студентів, емпіричне дослідження.

The study considers of the features emotional students excitability during the process of their professional training. There are psychological features of the emotional excitability and its main components analyzed in the study. Our research was conducted on student's first and fourth year students.

Emotional excitability is a personality trait, which is characterized by the ease of emergence for strong emotions, weakened self-control and general effectiveness of behavior. Emotional excitability can be manifested in such behavioral features as irascibility, irritability.

Emotional excitability characterized how strong the stimulus must be to cause an emotional response. The concept of emotional resilience is also important. It is characterized by emotional insensitivity, invulnerability of the emotional sphere from emotional stimulus. Emotional stability is the ability to control emotional reactions, which is manifested in patience, perseverance, self-control, endurance. All this items ensures the sustainability of efficiency and increase self-esteem.

There are a lot of different manifestations of emotional excitability and they can be diametrically opposite: we can see increased person's motor activity, impulsivity or, completely opposite reaction such as, calm, indifference, inactivity. In that case excitability will find expression in the form of increased associative activity (anxiety, with accompanied by a continuous flow of various uncontrolled thoughts and fantasies). Increased emotional excitability may be a prerequisite for a more dangerous syndrome as an emotional burnout.

Physiologists said that emotional excitability is the emotional readiness to react on significant stimuli for a person. Adrenaline plays a significant role in the formation of this readiness. Its introduction by the subjects led to the fact that they have emotional reaction on those stimuli which previously do not have any emotional reaction. Emotional excitability is influence on effectiveness of some professional activities.

A person with excessive emotional excitability feels and perceives those things that others may miss or not notice. They often ask friends and acquaintances for help and advice. Because of the intensity of their feelings and compassion for others, such people usually have very strong friendships. Their feelings for friends are very deep, so they always remain in the ranks of the most loyal friends.

Those who have emotional hypersensitivity have strong empathy for people, but little compassion for themselves. They are very self-critical and have a strong sense of responsibility even for things that are not entrusted to them.

Key words: emotional sphere, professional training of students, empirical research. 
Постановка проблеми. Проблема емоційного розвитку особистості є однією з найскладніших і маловивчених у психології. Емоції виконують оцінну, стимулюючу, регулюючу функції, а також функції, що активують, синтезують, допомагаючи людині жити й гармонійно розвиватися в навколишньому світі. Сучасний студент схильний до впливу різних негативних факторів, здатних підірвати емоційне здоров'я навіть психологічно сильної молодої людини. у зв'язку з цим очевидна необхідність більш детального, глибокого вивчення емоційної сфери особистості.

До основних властивостей емоційної сфери належать емоційна збудливість, емоційна стійкість, емоційна ригідність, зокрема лабільність, глибина переживання емоцій, емоційний відгук, експресивність.

Аналіз останніх досліджень і публікацій. Вивчення емоційної сфери людини взагалі та її емоційності зокрема нині є дуже актуальним. Удосконалювання технологій, засобів виробництва, засобів комунікації, інформаційних технологій робить наше життя більш зручним та комфортним, водночас ускладнює процес взаємодії людини-суб'єкта з об'єктом, і не тільки на рівні мислення, пам'яті, уваги, але й на емоційному рівні, який безпосередньо відіграє важливу роль у регуляції психічних процесів людини. Багато людей не встигає адаптуватися до нових навколишніх умов, що приводить до низки негативних наслідків як на професійному рівні, так і на психологічному рівні. Психічні розлади, депресії, дистреси, наркоманія та алкоголізм є наслідком емоційного не пристосування людини до навколишніх умов, тому як у повсякденному житті, так і в професійній сфері не можна сьогодні не враховувати ці факти.

Однією з найважливіших емоційних властивостей особистості $€$ емоційна збудливість. Емоційна збудливість - це ступінь готовності до емоційного реагування на значущі для людини подразники, вона виявляється через дратівливість, нестриманість, запальність, гарячковість, сприяє підвищенню чутливості, вразливості тощо. Емоційна збудливість характеризується тим, якої сили потрібен вплив, щоб викликати емоційну реакцію. Вона вказує на швидкість виникнення й перебігу реакцій.

Говорячи про легкість прояву емоцій, психолог Є.П. Ільїн, посилаючись на О.Ф. Лазурського, підкреслює, що про підвищену емоційну збудливість можна сказати лише тоді, коли всі почуття, властиві конкретній людині, виникають у неї однаково легко. Водночас під емоційною збудливістю нерідко розуміють легкість виникнення якоїсь однієї емоції, але, на думку вченого, в такому разі не йтиметься про порушення [2, с. 209].

Постановка завдання. Метою статті $€$ здійснення теоретичного науково-психоло- гічного аналізу підходів вітчизняних науковців до розуміння сутності емоційної збудливості; дослідження особливостей емоційної збудливості студентів на різних етапах навчання.

Виклад основного матеріалу дослідження. Емоційна збудливість $€$ однією з властивостей емоцій. Емоційно нестійкі, збудливі люди відгукуються навіть на слабкі впливи оточення, тоді як емоційно стійкі тільки на сильні.

О.Ф. Лазурський пише про те, що, спостерігаючи за різними людьми, ми бачимо, що одне почуття, яке їм властиво, починає проявлятися лише тоді, коли вплив умов досягає значної інтенсивності; тільки деякі незвичайні події здатні зруйнувати їхню байдужість і привести їх до стану певного порушення. Інші, навпаки, за будь-якого невеликого приводу спалахують, начебто порох, хвилюються, закипають, доходять до стану захопленості або подиву. О.Ф. Лазурський вважає, що про емоційну збудливість можна говорити лише тоді, коли всі почуття, якими людина володіє, виникають у неї з однаковою легкістю [4, с. 142].

Емоційну ригідність О.Ф. Лазурський визначав як той найбільший для людини відрізок часу, протягом якого емоція, що один раз виникла, продовжує проявлятися, незважаючи на те, що обставини змінилися, а подразник припинив діяти. Емоційно ригідні відрізняються «в'язкістю» емоцій, їхньою стійкістю. Емоційна «в'язкість» пов'язана з фіксацією уваги й афекту на якихось важливих подіях, об'єктах, психотравмуючих обставинах, невдачах, що хвилюють індивіда. Нестійкість емоції, за О.Ф. Лазурським, проявляється в тому, що, незважаючи на її споконвічну інтенсивність, вона швидко слабшає й, зрештою, припиняється, переходить у стан спокійної байдужості. Якщо ж емоції людини легко збудливі, то попередня емоція дуже швидко змінюється на іншу, ця інша - на третю. Відбувається швидка й різка зміна емоцій і настрою, характерна для людей істеричного складу характеру [4, с. 74].

Емоційна лабільність властива особам 3 високим нейротизмом (тривожністю). Навпаки, низькому нейротизму властива емоційна ригідність. Занадто виражена лабільність емоцій може ускладнювати відносини з оточуючими людьми, тому що особистість стає реактивною, імпульсивною, погано керує собою. Емоційна стійкість - це єдність різних емоційних характеристик, які спрямовані на досягнення поставленої мети. Головним критерієм емоційної стійкості для багатьох учених $\epsilon$ ефективність діяльності в неспецифічній для людини ситуації.

Я. Рейковський визначає емоційну стійкість як здатність емоційно збудженої людини зберігати певну спрямованість своїх дій, адекватне функціонування й контроль за проявом емоцій [5, с. 186]. 
К.К. Платонов виділяє в емоційній стійкості такі компоненти, як емоційно-вольовий (ступінь вольового володіння людиною своїми емоціями), емоційно-моторний (стійкість психомоторики), емоційно-сенсорний (стійкість сенсорних вражень) [1, с. 275].

Емоційна збудливість може проявлятися в таких особливостях поводження, як запальність, дратівливість. Стосовно явища запальності К. Ізард вважає за необхідне ввести поняття «емоційний поріг». Людина з низьким порогом емоції гніву більше запальна й частіше перебуває в цьому стані [1, с. 293].

Прояви підвищеної емоційної збудливості різні, аж до діаметрально протилежних: у людини може спостерігатися підвищена рухова активність, імпульсивність, або, навпаки, людина буде здаватися абсолютно спокійною, байдужою, нерухомою, проте збудливість знайде своє вираження у вигляді посилення асоціативної активності (почуття сильного занепокоєння, тривоги, що супроводжується безперервним потоком різних неконтрольованих думок і фантазій). Підвищена емоційна збудливість може стати передумовою виникнення більш небезпечного синдрому, а саме емоційного вигорання [3, с. 75].

Важливо відзначити, що дещо підвищений рівень збудливості не завжди свідчить про проблеми. Під час аналізу емоційної сфери конкретної людини не слід виключати індивідуальні особливості особистості, такі як вік (так, підлітковий вік з огляду на свої особливості, на думку низки авторів, часто супроводжується високим рівнем збудливості, нестійкості, агресивності, тривожності особистості), темперамент (наприклад, у холериків відзначається більш високий рівень збудливості) і навіть стать (Є.П. Ільїн, П.А. Ковальов констатують, що у жінок рівень емоційної збудливості і нестійкості вище, ніж у чоловіків) [2, с. 471].

У дослідженнях $€$.П. Ільїна також зазначається, що до поняття емоційної збудливості фактично дуже близьке поняття емоційної чуйності, під якою мається на увазі «стійка властивість індивіда, що виявляється в легкому, швидкому і гнучкому емоційному реагуванні на різноманітні впливи» [2, с. 365].

Отже, під емоційною збудливістю розуміють швидкість виникнення почуттів (емоцій) і їхню силу. У темпераменті виділяють дві властивості емоційності, а саме емоційну збудливість та силу емоцій. Перша властивість означає емоційну чутливість, друга - енергетичну сторону виниклої емоції, тобто відзначають в емоційності її динамічну сторону. Також у широкому аспекті під емоційною стійкістю можна розуміти здатність управляти своїми емоціями, зберігати високу професійну працездатність, здійснювати складну або небезпечну діяльність без напруженості, незважаючи на емоціогенний вплив. Далі можна привести більш вузьке визначення емоційної стійкості, позначаючи ії як інтегративну полісистемну якість індивіда, обумовлену змістом і взаємозв'язком його складових частин, що системно обумовлює продуктивність діяльності й адекватність поводження в екстремальних стресових умовах. Таким чином, емоційна стійкість характеризується емоційною нечутливістю, невразливістю емоційної сфери особистості до дії емоційних подразників. В наведених характеристиках емоційної стійкості зроблено акцент на здатності контролювати емоційні реакції, що проявляється в терплячості, наполегливості, самоконтролі, витримці; все це забезпечує стійкість ефективності діяльності та підвищення самооцінки.

Емоційна збудливість характеризується тим, якої сили потрібен вплив, щоб викликати емоційну реакцію. Важливим $є$ також поняття емоційної стійкості, яке характеризується емоційною нечутливістю, невразливістю емоційної сфери особистості до дії емоційних подразників, здатністю контролювати емоційні реакції, що проявляється в терплячості, наполегливості, самоконтролі, витримці. Все це забезпечує стійкість ефективності діяльності та підвищення власної самооцінки.

3 точки зору фізіології, емоційна збудливість $€$ ні чим іншим, як емоційною готовністю, тобто готовністю емоційно реагувати на значущі для людини подразники. Істотну роль у формуванні цієї готовності відіграє адреналін. Його введення досліджуваним зумовлювало те, що вони починали виявляти емоційні спалахи на ті подразники, які раніше залишали їх зовсім спокійними [3, с. 196].

Емоційна збудливість $є$ особистісною особливістю, для якої характерні легкість виникнення сильних емоцій, ослаблений самоконтроль і загальна ефективність поведінки.

Дослідження емоційної збудливості студентів на різних етапах навчання ми проводили на базі Національного університету цивільного захисту України. В дослідженні взяли участь студенти першого курсу (в кількості 25 осіб) та студенти четвертого кусу (в кількості 25 осіб) соціально-психологічного факультету.

Емоційна збудливість характеризується швидкістю виникнення, протікання й зміни емоційного відгукунапевний подразник. Люди, які мають високий показник емоційної збудливості, характеризується легкістю виникнення сильних емоцій, ослабленим самоконтролем, загальною ефективністю поведінки.

Для виявлення рівнів емоційної збудливості наших досліджуваних ми використали методики, які нам дадуть змогу дізнатися те, наскільки збудливими чи, навпаки, спокійними $€$ наші досліджувані. Ми використали методики «Емоційна збудливість/врівноваженість» (Б.М. Смірнов), «Експрес-діагностика некерованої емоційної збудливості» (В.В. Бойко). 
Після проведення та оброблення результатів методики «Емоційна збудливість/врівноваженість» ми отримали результати, які свідчать про те, що 15\% студенти першого курсу мають дуже високий рівень емоційної збудливості, $20 \%$ мають високий. Більша частина студентів-першокурсників володіє середнім рівнем емоційної збудливості (40\%). Низька емоційна збудливість притаманна 20\%. Майже емоційно незбудливих досліджуваних, які мають дуже низький рівень збудливості, є лише 5\%.

Група студентів четвертого курсу на дуже високому та високому рівнях емоційної збудливості набрали лише по 5\%. Середній рівень емоційної збудливості мають 35\% студентів цієї групи. Майже вполовину менше досліджуваних отримали низький рівень, а саме $20 \%$. Аж 35\% можуть бути задоволеними дуже низькою емоційною збудливістю.

Таким чином, можна зробити висновок, що у студентів першого курсу більш виражені середній і високий рівні емоційної збудливості, що свідчить про те, що вони є більш запальними, дратівливими, нестриманими та більш емоційно чутливими, а у студентів четвертого курсу значно переважає дуже низький рівень емоційної збудливості, що характеризує їх як урівноважених, витриманих, безпристрасних, спокійних людей.

Розглянемо результати методики «Експрес-діагностика некерованої емоційної збудливості» (В.В. Бойко).

Високий рівень некерованої емоційної збудливості переважає у студентів першого курсу, складаючи $45 \%$, а у студентів четвертого курсу цей показник становить 5\%. Цим досліджуваним потрібна мінімальна сила впливу подразника, щоб емоційно відреагувати.

Середній рівень в обох групах становить $40 \%$, тобто студенти обох груп однаковою мірою мають середній рівень некерованої емоційної збудливості, а низький рівень переважає у групі студентів четвертого курсу (55\%), у студентів першого курсу цей показник становить $15 \%$, студенти з цими даними відрізняються спокійністю, стриманістю та урівноваженістю.

За даними цієї методики ми можемо зробити висновок, що у студентів четвертого курсу найбільше виражений низький рівень (55\%) некерованої емоційної збудливості, що свідчить про те, що імпульсивність у цій групі майже відсутня, а у студентів першого курсу більш виражений високий рівень некерованої емоційної збудливості, отже, студентам-першокурсникам імпульсивність властива більше, ніж студентам четвертого курсу. Імпульсивність - це риса характеру, що виражається в схильності діяти без достатнього свідомого контролю над собою, під впливом зовнішніх обставин або з огляду на емоційні переживання, вона властива більш емоційним людям.
Висновки 3 проведеного дослідження. Однією з найважливіших емоційних властивостей особистості $€$ емоційна збудливість. Вона характеризується тим, якої сили потрібен вплив, щоб викликати емоційну реакцію. Вона вказує на швидкість виникнення й перебігу реакцій. Емоційно нестійкі, збудливі люди відгукуються навіть на слабкі впливи оточення, тоді як емоційно стійкі - тільки на сильні.

Провівши своє дослідження щодо вивчення особливостей емоційної збудливості студентів на різних етапах навчання, ми отримали дані, які свідчать про те, що у студентів першого курсу більш виражені середній і високий рівні емоційної збудливості, що свідчить про те, що вони є більш запальними, дратівливими, нестриманими та більш емоційно чутливими, а у студентів четвертого курсу значно переважає дуже низький рівень емоційної збудливості, що характеризує їх як урівноважених, витриманих, безпристрасних, спокійних людей.

Також було виявлено, що у студентів четвертого курсу найбільше виражений низький рівень (55\%) некерованої емоційної збудливості, що свідчить про те, що імпульсивність у цій групі майже відсутня, а у студентів першого курсу більш виражений високий рівень некерованої емоційної збудливості, отже, студентам-першокурсникам імпульсивність властива більше, ніж студентам четвертого курсу. Імпульсивність це риса характеру, що виражається у схильності діяти без достатнього свідомого контролю над собою, під впливом зовнішніх обставин або з огляду на емоційні переживання, вона властива більш емоційним людям.

Таким чином, студенти четвертого курсу здатні контролювати свій гнів, роздратування, здатні регулювати свої емоції, приводячи їх у порядок, здатні поводитися, як того вимагає ситуація. Пояснити це можна тим, що чим більше впевнена в собі людина, чим більш вона може на себе розраховувати, тим більше ймовірно, що вона швидко та впевнено впорається з виниклою непередбаченою ситуацією без проявляння зайвих емоцій. Це можна пояснити тим, що студенти четвертого курсу вже адаптувалися до навчання, більш впевнені у своїх силах, більш стримані та розсудливі.

\section{ЛІТЕРАТУРА:}

1. Изард К. Психология эмоций. Санкт-Петербург : Питер, 1999. 464 с.

2. Ильин Е.П. Эмоции и чувства. Санкт-Петербург : Питер, 2001. 752 с.

3. Кириленко Т.С. Психологія: емоційна сфера особистості : підручник. Київ : Либідь, 2007. 256 с.

4. Лазурский А.Ф. Очерк науки о характерах. Москва : Наука, 1995. 207 с.

5. Рейковский Я. Экспериментальная психология эмоций. Москва : Прогресс, 1979. 392 с. 